\title{
PENGEMBANGAN RUANG KOTA SAMARINDA DENGAN MENERAPKAN METODE TEKNIK ANALISA URBAN
}

\author{
(THE DEVELOPMENT OF SAMARINDA URBAN SPACE BY \\ IMPLEMENTING METHODS OF URBAN ANALYSIS TECHNIQUE )
}

\author{
Edith Abram Rochdi \\ Universitas Nahdlatul Ulama Kalimantan Timur-Teknik Arsitektur \\ Jl. KH. Harun Nafsi Gg. Dharma, kel. Rapak Dalam, kec. Loa Janan Ilir, \\ telp/fax. 0541-7269413, Samarinda \\ Email: unukaltim@gmail.com; edithabram_rochdi@yahoo.com
}

Diterima: 1 April 2020; Direvisi: 25 Juni 2020; Disetujui: 26 Juni 2020

\begin{abstract}
ABSTRAK
Apabila dilihat secara keseluruhan, maka pada sebuah kota yang ada merupakan suatu leburan atau penyatuan dari bangunan dan penduduk. Pada awalnya bentuk kota adalah netral yang kemudian berubah sampai saat ini sesuai dengan kondisi masing-masing sebuah kota. Terbentuknya kota tergantung lokasi dan letak geografinya yang sangat mempengaruhi karakteristik kotanya. Hal ini tentunya juga budaya tertentu memberikan peran serta dalam pembentukan sebuah kota. Pengembangan kota perlu diperhatikan penataannya agar terarah tatanan ruang kotanya dan mempunya karakteristik tersendiri. Demikian juga dengan kota Samarinda yang sekarang ini makin berkembang dengan pesat perlu dijaga penataan ruang kotanya agar tidak kumuh dan berciri khas. Sebelum dilakukan penataan ruang kota pada kawasan tertentu yang dipentingkan terutama pada koridor sungai Mahakam, maka bentuk kota ini dapat dipelajari dan dikaji secara tinjauan lapangan dengan mengamati kondisi eksisting. Disini perlu dibantu beberapa metode dan teknik analisa urban. Metode dan teknik analisa ini merupakan analisa perancangan kota atau urban design analysis untuk mendapatkan kesimpulan karakteristik bentuk morfologi kota yang bisa direkomendasikan nantinya untuk penataan ruang kotanya.
\end{abstract}

Kata kunci: Ruang Kota, Samarinda, Teknik Analisa Urban.

\begin{abstract}
When viewed as a whole, then in an existing city is a fusion or a union of buildings and residents. At first the form of the city was neutral which then changed to the present according to the conditions of each city. The formation of cities depends on their location and geographical location which greatly influences the characteristics of the city. This of course also certain cultures give a role in the formation of a city. The development of the city needs to be considered in its arrangement so that the urban spatial structure is directed and has its own characteristics. Likewise, the city of Samarinda, which is growing rapidly, needs to be maintained so that the spatial planning of the city so that it is not dirty and has a distinctive characteristic. Before urban spatial planning is carried out in certain areas of particular importance in the Mahakam river corridor, the shape of the city can be studied and studied in a field review by observing existing conditions. Here need to be assisted by several methods and techniques of urban analysis. This analysis method and technique is an urban design analysis to get a conclusion about the characteristics of the city morphology that can be recommended later for spatial planning of the city.
\end{abstract}

Keywords: Urban space, Samarinda, Urban analysis technique.

\section{PENDAHULUAN}

Menurut Kostof (1991) kota adalah tempat kumpulan bangunan dan manusia. Kota perlu dilakukan analisa berupa analisa urban atau bisa disebut analisa kota yang digunakan dalam perancangan kota untuk melihat karakteristik kota sebelum dilakukan pengembangan kotanya. 
Analisa kota yang dilakukan saat ini terfokus pada lokasi di kota Samarinda provinsi Kalimantan Timur. Lokasi yang dipilih dipertimbangkan dengan adanya banyak kemungkinan kota Samarinda dengan luas 71.800 ha akan bisa tumbuh dan berkembang menjadi kota metropolitan, mengingat jumlah penduduk sampai saat ini sudah mencapai 1 (satu) juta jiwa bahkan lebih, tentunya dalam pembahasan mengenai analisa kota ini terhadap morfologi ruang kota akan ditemukan karakteristik fisik dari kota ini.

Untuk dapat memahami perkembangan sebuah kota secara fisik, maka perlu pendekatan terhadap metode dan teknik analisa kota yang tentunya bisa dikembangkan satu sama lain dengan melihat kepentingan kota Samarinda terhadap pengembangan ruang kota terkait dengan bentuk pola ruang kota. Dengan melihat kondisi pola ruang kota maka kita dapat menata suatu kawasan. Pengembangan ruang kota saat ini lebih diarahkan pada kawasan koridor sepanjang Sungai Mahakam. Hal ini mengarah kepada kepentingan penataan koridor dalam lingkup secara kawasan. Kawasan ini memberikan citra fisik yang khas sebagai sebuah kota air yang mempunyai tepian sungai yang cukup lebar yang banyak dikunjungi masyarakat untuk wisata pada malam hari saat ini.

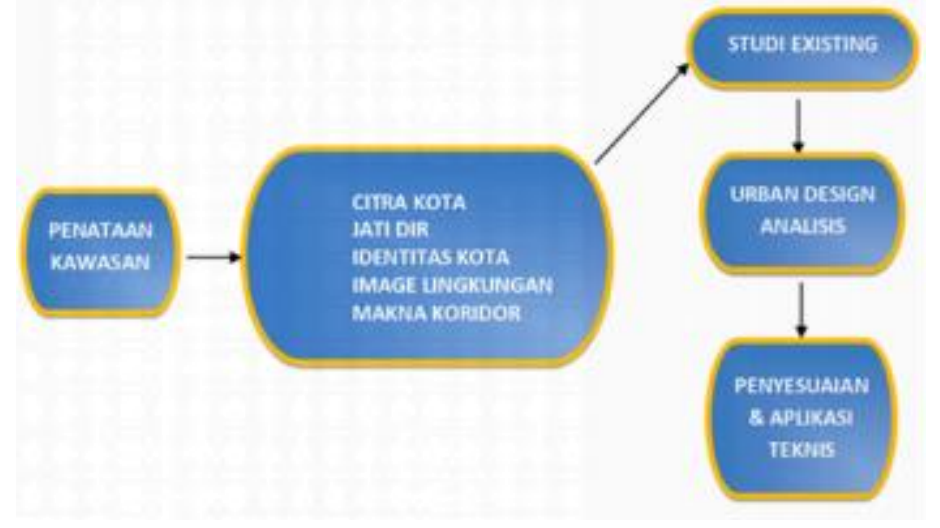

Gambar 1. Pentahapan analisa kota Samarinda melalui pendekatan morfologi kota, Sumber: Hasil Pemahaman Penulis berdasarkan survei (2012)

Kawasan ini perlu dikaji lebih lanjut terhadap penataannya mengarah pada beberapa aspek berupa citra kota, jati diri, identitas kota, image lingkungan dan makna koridor melalui pendekatan morfologi kota yang lebih mengarah pada analisa perancangan kota atau urban design analisis. Citra kota dipahami sebagai suatu gambaran khas melekat pada kota yang menciptakan representasi kota pada masyarakat sekitar maupun pengamat yang datang pengunjung. Citra kota umumnya dipengaruhi oleh aspek fisik kota. Menurut Lynch (1960) dalam bukunya: Image of the city, menyebutkan ada 5 (lima) elemen pembentuk citra kota secara fisik yaitu path (jalur), edge (tepian/pembatas), district (kawasan), nodes (simpul) dan landmark (penanda/tetenger). Jati diri dipahami sebagai ciri khusus dalam suatu daerah yang bisa dijadikan icon. Menurut Lynch (1976) identitas kota dipahami sebagai suatu kondisi pada suatu kota yang mempunyai citra metal berupa karakter dan keunikan tersendiri yang sudah mengakar dan mudah diingat serta dikenali oleh masyarakat berdasarkan kehidupan sosial, ekonomi dan budaya masyarakat kota itu sendiri, yang terbentuk melalui ritme biologis tempat dan ruang tertentu yang mencerminkan waktu. Identitas kota digunakan untuk membedakan dan mengenali antara tempat satu dengan lainnya. Menurut Lynch (1960) untuk dapat memahami identitas kota maka terlebih dulu mengenali citranya. Image lingkungan dipahami kecenderungannya lebih terfokus pada lingkungan setempat sebagai pengenalan bentuk dan ruang yang paling sederhana, disebut sense of place (Lynch,1976) yang merupakan penilaian keunikan suatu tempat khusus. Makna koridor dipahami sebagai arti penting dari sebuah koridor yang memberikan fungsi dan karakter khusus yang memberikan peranan yang spesifik 
dalam suatu tempat. Koridor disini dimaksudkan sebagai suatu lorong yang menghubungkan gedung satu dengan lainnya. Dalam pemahamannya koridor merupakan bagian ruang kota yang membentuk sirkulasi jalan.

\section{METODE}

Beberapa teknik analisa kota ini diantaranya adalah: legability analisis, mapping analisis, ped-shed analisis, space syntax analisis, tissue analisis, transportation and traffic modelling, urban design audit, tipo morfologi analisis dan walkthrough analisis. Terdapat 9 (sembilan) metode analisa kota (Ministry for the Environment, 2006) yang tidak semuanya dipakai dalam menganalisa kota Samarinda. Perlu dilakukan seleksi sebatas yang diperlukan dengan kepentingan pengembangan ruang kota Samarinda. Disamping itu teknik analisa yang dipilih berdasarkan pada pertimbangan kemudahan pemahaman dalam aplikasi dilapangan yang nantinya mampu mengkuantitaskan data yang kualitatif dengan kesederhanaan analisa yang ada.

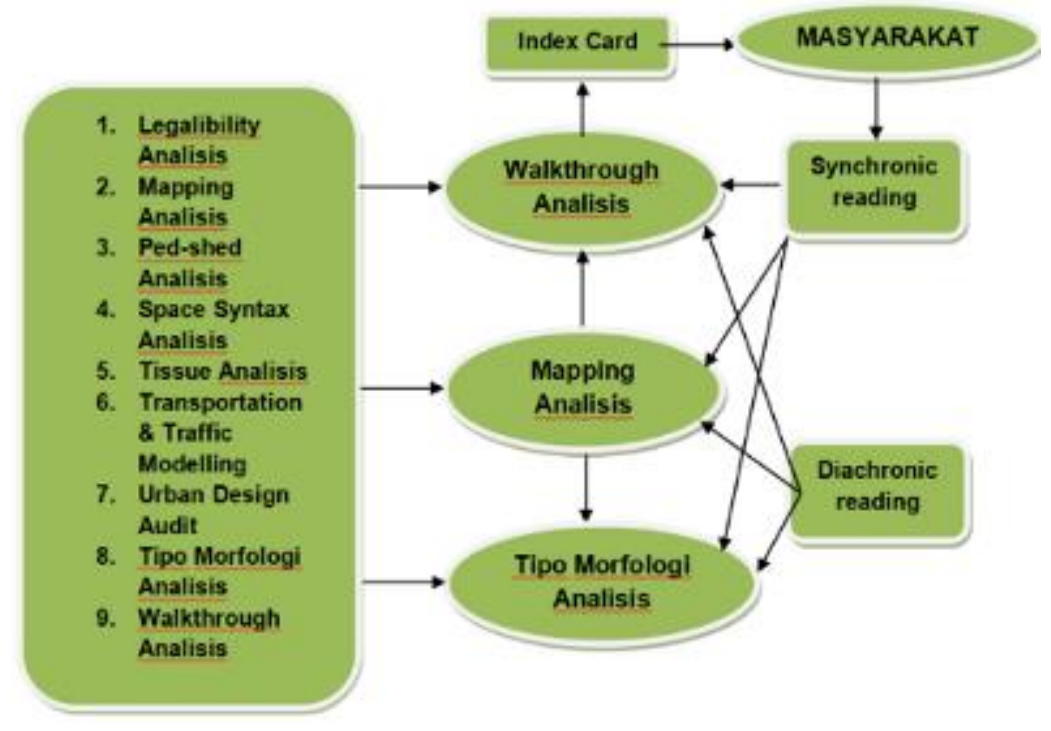

Gambar 2. Metode dan Teknik Analisa Urban,

Sumber: Hasil pemahaman Urban Design Toolkit (2006)

Hasil pemilihan teknik analisa tidak murni diterapkan sepenuhnya, namun mengalami modifikasi dan pengaruh teknik analisa lainnya dikarenakan kepentingan dari penataan kawasan itu sendiri. Bahkan setiap teknik analisa yang dipilih tidak berdiri sendiri tapi bisa salah satu teknik analisa mendukung teknik analisa lainnya.

Teknik analisa walkthrough, mapping dan tipo morfologi adalah pilihan yang tepat untuk membantu pembuatan analisa kota Samarinda, karena dapat mewakili kepentingan pengembangan ruang kotanya. Pada 3 (tiga) analisa kota ini didukung teknik pembacaannya dalam menyampaikan data dengan cara synchronic reading berupa menyelaraskan berbagai informasi yang didapat pada saat yang sama dan diachronic reading berupa penelusuran asal usul sejarah (Darjosanjoto, 2006) untuk membantu ketiga analisa dalam mendapatkan data yang kualitatif dan dapat dipertanggung jawabkan. Teknik analisa walkthrough menghasilkan data visual yang nantinya bisa disampaikan ke masyarakat untuk mendapatkan tanggapan dan aspirasinya dalam membantu teknik analisa lainnya dengan dibantu pembuatan index card berupa data tabel yang informatif. Teknik analisa mapping dipakai untuk mendukung data Analisa walkthrough dan tipo morfologi agar tercapai hasil data yang bisa disampaikan secara grafis. Teknik analisa tipo morfologi berupa penerapan prinsip morfologi ruang kota mengarah terjadinya bentuk ruang luar terhadap struktur jalan (berpedoman pada diagram gambar 2 
diatas). Dengan demikian ketiga teknik analisa ini bisa berjalan secara simultan mendukung satu sama lain dalam pelaksanaan analisa kota.

\section{HASIL DAN PEMBAHASAN APLIKASI TEKNIK ANALISA KOTA Walk Through Analisis}

Teknik ini merupakan suatu cara untuk bisa menjelaskan kondisi kualitas dan kuantitas ruang luar yang terjadi termasuk tekstur jalan, areal pejalan kaki, lansekap dan elemen penunjang lain yang di amati dan terekam dalam foto setiap sudut ruang kota. Dalam hal ini secara street view phototographic yang dipakai yang utama banyak dalam teknik penyajian single directional views saja, sedangkan teknik penyajian serial view dan linear side views (Parsons, 2010) hanya sebagian saja dipakai. Disini pengamatan melalui akses dari pejalan kaki yang menelusuri koridor sepanjang Sungai Mahakam dimulai dari Jl. Yos Sudarso (Pelabuhan Kapal Penumpang) sampai ke Jl. Selamet Riyadi (Jembatan Mahakam).
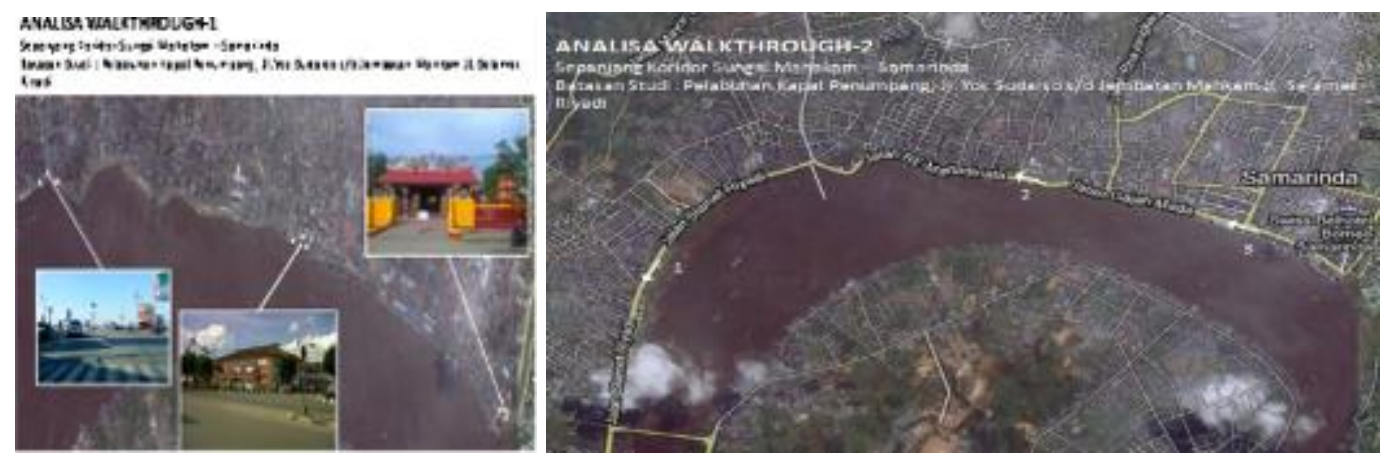

Gambar 3. Teknik Analisa Walkthrough,

Sumber: Hasil survey dan google.co.id/maps/kota-samarinda(2012)

Pada Walk through analisis ke-1 street views photographic yang diambil hanya pada titik simpul pertemuan Jl. Selamet Riyadi, Jl. Antasari dan Jl. Martadinata yang terhubung dengan koridor jalan sepanjang sungai mahakam. Hasil pengamatan/pengambilan data memperlihatkan tampilan beberapa pojok simpul jalan yang mengidentitaskan nodes tentang tipologi bangunan yang nantinya akan lebih diperinci pendataan foto dengan teknik penyajian diachronic dengan adanya perubahan bentuk transformasi bangunan dari tahun ketahun. Bangunan yang lama pada saat sekarang trendnya dengan cara menyelubungi bangunan lama dengan lapisan Aluminium Composit Panel atau biasa disebut Alucubon.

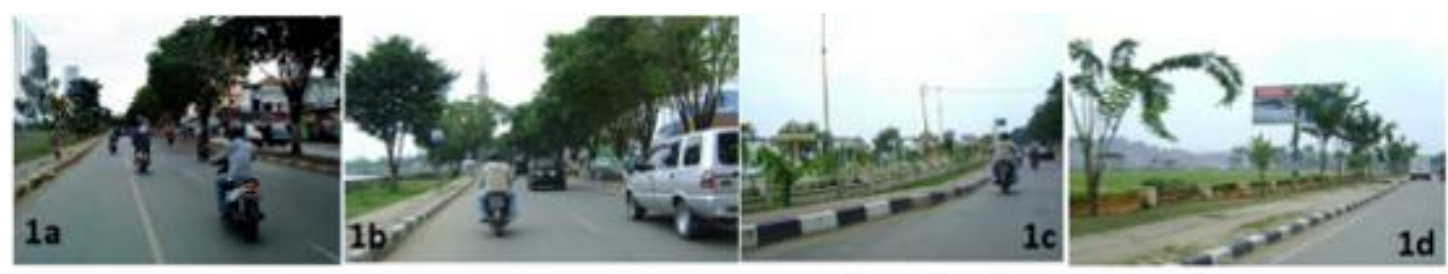

Gambar 4. Street View-1 a,b,c,d di jl. Slamet Riyadi, Sumber: Hasil survey (2012)

Pada Walkthrough analisis ke-2 (dua) ini ada 3 (tiga) bagian jalan koridor jalan disepanjang sungai mahakam yang memperlihatkan secara path pada masing-masing kondisi street furniture berupa public space area, aktifitas sektor informal, RTH (ruang terbuka hijau), jalur pedestrian, parit kota, facade bangunan, sky line, papan reklame, bahu jalan dan bentuk dan massa bangunan disepanjang jalan. Disini ada perbedaan kondisi fisiknya pada setiap ruas jalan pada 3 (tiga) bagian jalan ini. Perbedaannya pada bentuk street furniture dalam hal jenis dan 
jarak pohon yang ditanam, penyelesaian tekstur dan lebar trotoir, kondisi jalan dalam bentuk satu atau dua arah, kesan terhadap bentuk jalan yang berbelok atau tidak, kesan pandangan terhadap tinggi, jarak dan bentuk arsitektural bangunannya.

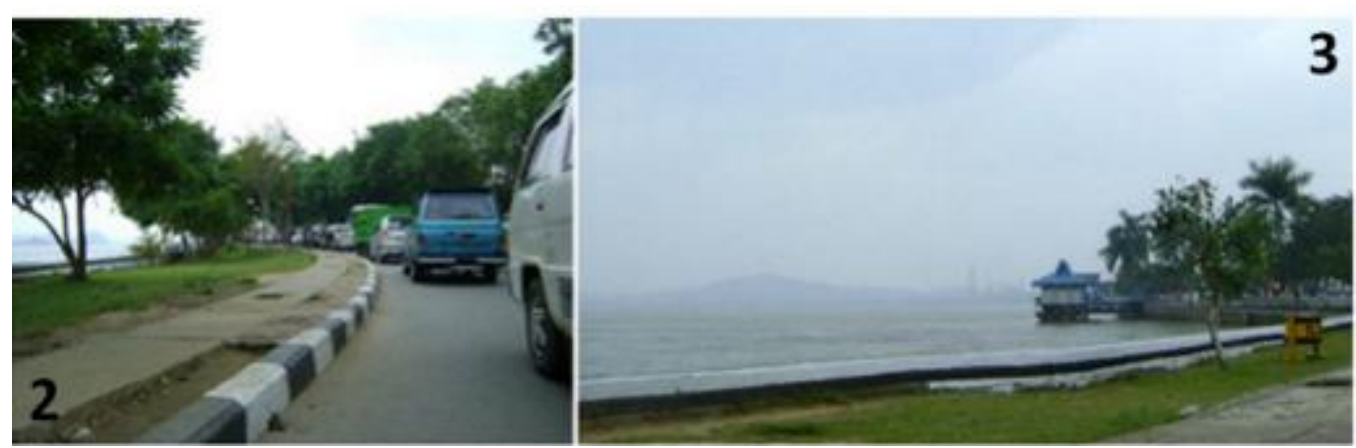

Gambar 5. Street View-2 di jl. RE. Martadinata dan Street View-3 di Jl. Gajah Mada, Sumber: Hasil survey (2012)

Kondisi street furniture pada teknik analisa walkthrough didukung dengan gambar potongan melintang jalan sebagai data kuantitas yang dibantu dengan pengukuran dilapangan untuk setiap ruas jalan. Secara grafis bisa menunjukkan jarak permasing-masing elemen jalan yang saling mendukung seperti halnya parit kota, pedestrian, boulevard, taman dan sebagainya. Dengan demikian menunjukkan bahwasanya posisi sungai dan elemen pendukung street furniture memberikan karakter tersendiri untuk setiap ruas jalan. Pada J1. Slamet Riyadi terdapat areal Islamic Center, J1. R.E. Martadinata terdapat pertemuan Sungai Mahakam dengan anak sungainya dan merupakan kawasan kuliner dan ruko pada sepanjang jalannya dan Jl. Gajah Mada merupakan kawasan perkantoran dan dinas pemerintahan.
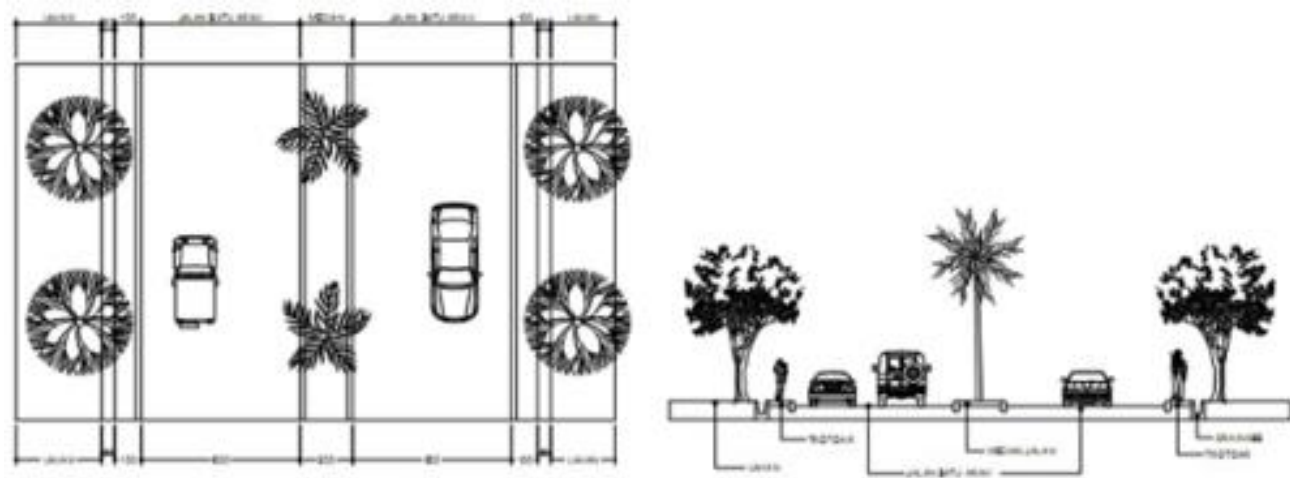

Gambar 6. Contoh Visual Street View dan Potongan Melintang Jalan, Sumber: Hasil pemahaman Urban Design Toolkit (2006)

\section{Mapping Analisis}

Analisa ini menggunakan sarana Peta sebagai data aktual yang nantinya bisa secara terperinci bisa menjelaskan kondisi batas jalan, penempatan distribusi ruang terbuka beserta sarana prasarananya, tipe jalan, ruang publik dan privat, juga arah distribusi elemen lansekap.

Pada analisa ini dapat dikembangkan dengan menambah foto untuk menjelaskan kondisi kawasan cepat tumbuh maupun pusat pertumbuhan kota Samarinda, juga termasuk jangkauan sarana jembatan penghubung antara Samarinda Kota dan Samarinda Seberang yang dipersiapkan menjadi kota mandiri untuk di kecamatan Samarinda Seberang dan kota industri untuk di kecamatan Palaran. 
Penentuan letak Pusat Pertumbuhan Kota atau titik mula kota Samarinda mulai tumbuh juga didasarkan pada data peta lama dari arsip di masa penjajahan Belanda pada masa dulu yang menjadi acuan dimasa sekarang. Dari hasil teknik analisa mapping-1,2 yang ada bisa terbaca bahwa Samarinda merupakan kota yang sudah berkembang cepat. Saat ini pusat pelayanan yang sekaligus berfungsi sebagai CBD (Central Bisnis Distric) berada dipusat kota lama sebagai awal pertumbuhan kota yang telah menjadi komplek Perkantoran dan Perdagangan. Sekarang ini CBD berubah dari pusat pelayanan retail (eceran) menjadi kompleks kegiatan perkantoran yang komersial dengan daya jangkauan pelayanan dapat mencakup bukan wilayah kota saja, tetapi mencapai kewilayah sekeliling kota sebagai wilayah pengaruh kota.

Sub pusat kota (Regional Centre) saat ini sudah mulai berkembang terutama didaerah Samarinda Seberang dan Palaran yang mana dulunya masih dilayani oleh CBD, sekarang sudah dilayani oleh sub pusat sendiri. Daerah pinggiran kota atau Outer Suburd yang merupakan perluasan wilayah kegiatan kota dilayani sepenuhnya oleh sub pusat.

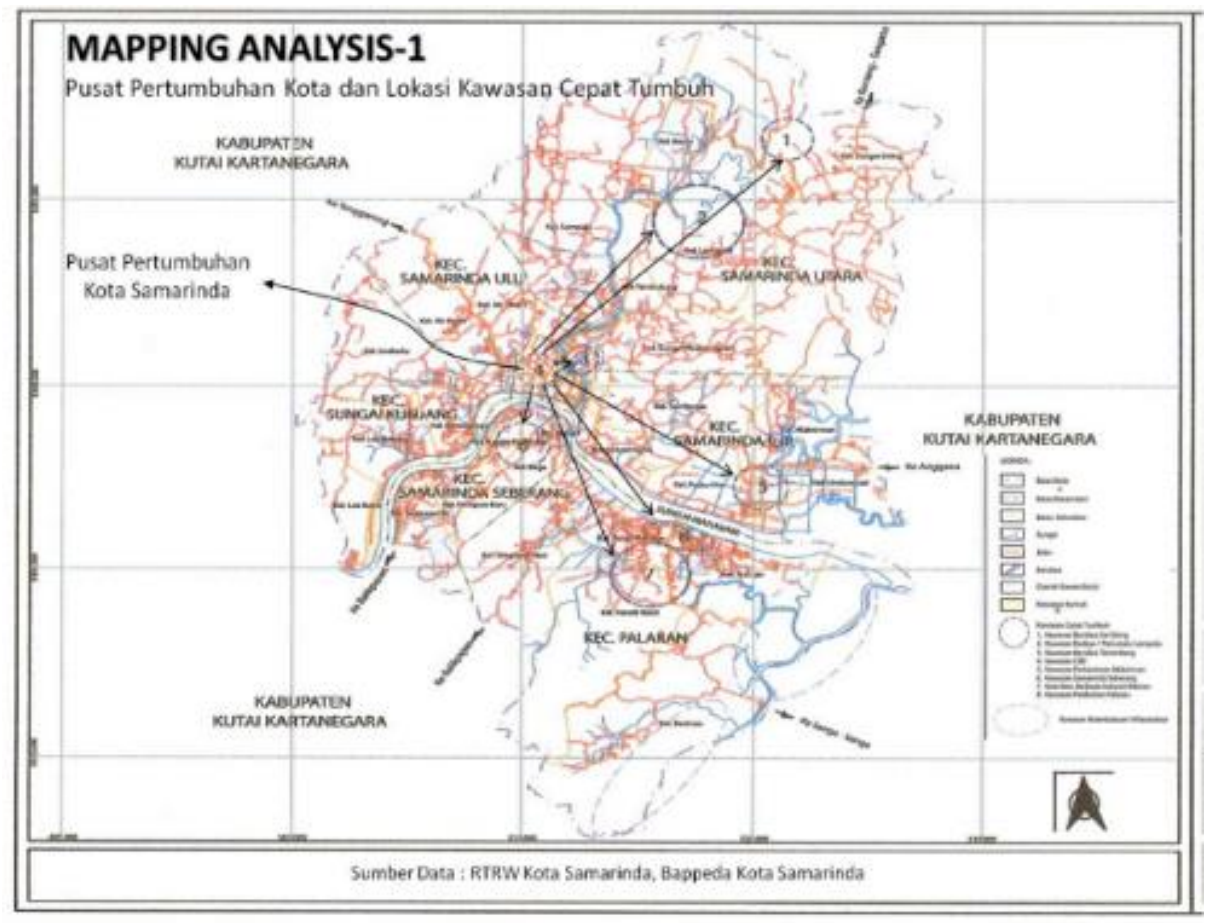

Gambar 7. Peta Kota Samarinda untuk mapping analisis-1, Sumber: Bappeda Kota Samarinda (2004)

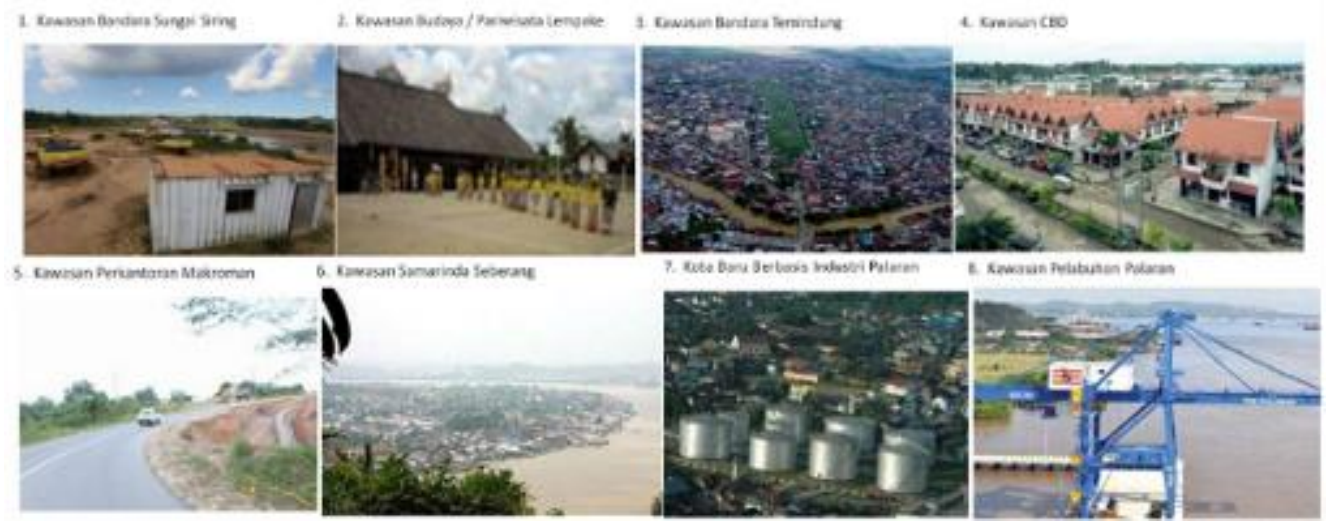

Gambar 8. Foto lokasi kawasan cepat tumbuh di Samarinda, Sumber: bappeda.samarinda kota.go.id(2012) 


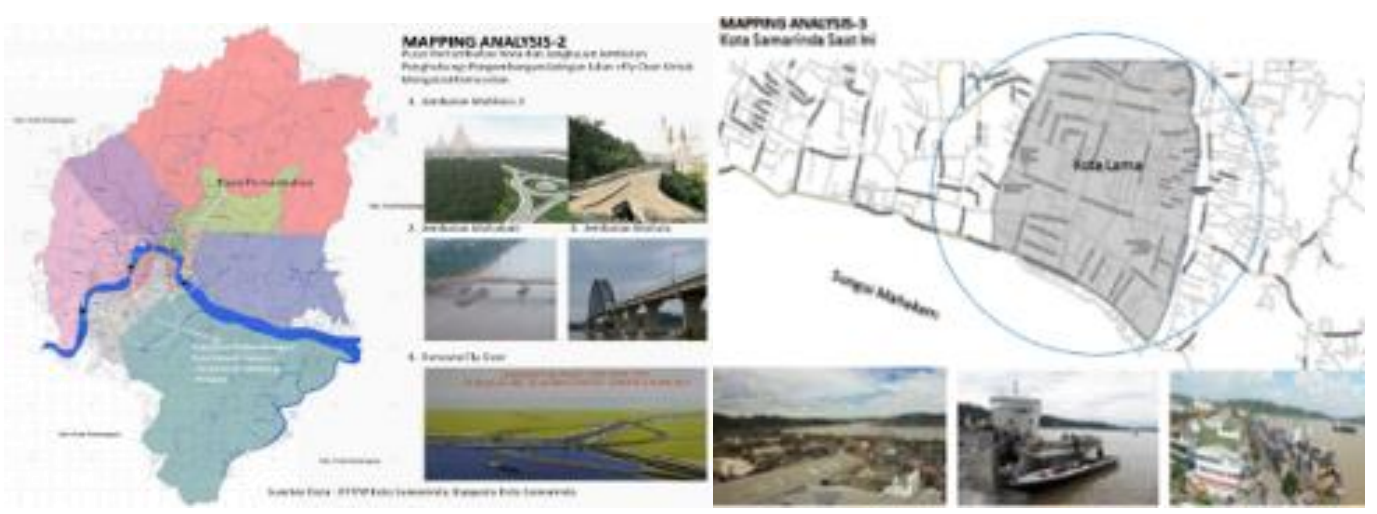

Gambar 9. Peta Kota Samarinda dan Perletakan Jembatan Layang untuk mapping analisis-2, Peta Kota Samarinda, letak dan kondisi Kota Lama untuk mapping analisis-3,

Sumber: Bappeda Kota Samarinda (2004), google map, google dan hasil survey (2012)

Disini teknik analisa mapping-3 yang ada dipakai untuk menjelaskan asal usul Samarinda dalam proses pertumbuhan kota lama menjadi kota saat ini. Termasuk juga menjelaskan struktur jalan dari kondisi yang dulu menjadi seperti yang sekarang ini. Disini akan terlihat pola ruang luar yang tumbuh dan berkembang menjadi seperti sekarang ini, yang dibantu dengan foto suasana kota dimasa dulu dengan masa sekarang.

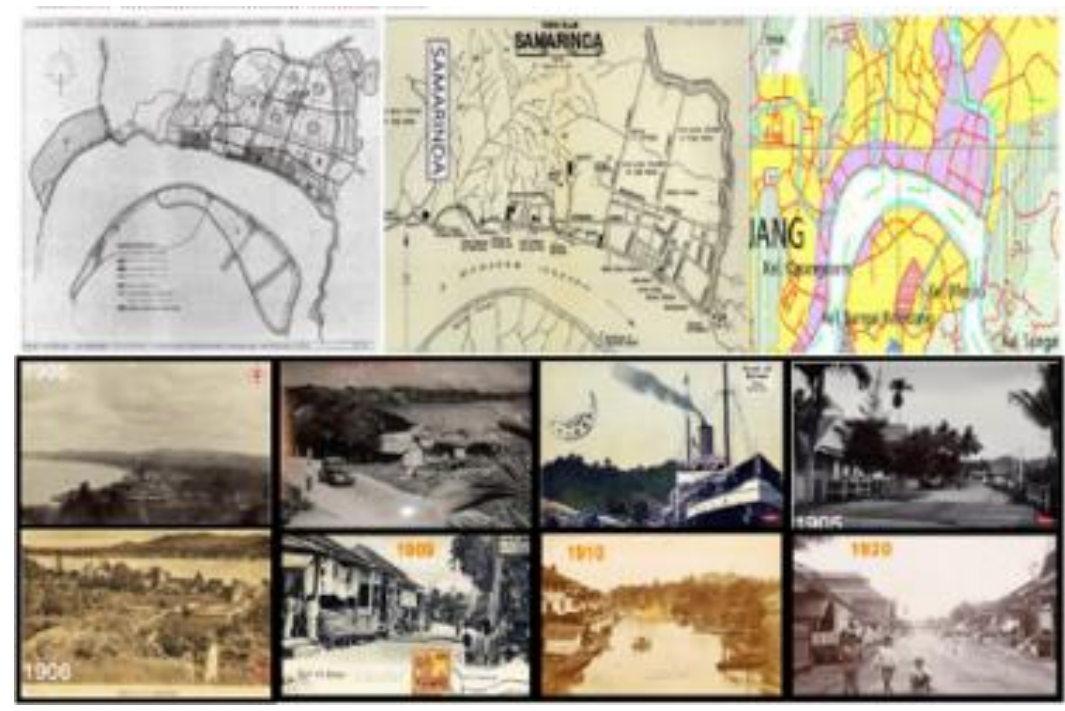

Gambar 10. Perbandingan peta dan foto kota Samarinda lama (1949-1950) dengan kota Samarinda saat ini, Sumber: bappeda.kaltimprov.go.id(2012)

\section{Tipo Morfologi Analisis.}

Teknik Analisis ini berpedoman pada prinsip morfologi ruang kota. Kajiannya mengarah pada terjadinya bentuk ruang luar yang dikaitkan dengan tersusunnya jalinan struktur jalan yang terjadi. Dengan demikian nantinya akan bisa dilihat bentuk morfologi ruang kota menjadi bentuk yang kompak (bujur sangkar, empat persegi panjang, bentuk kipas, bentuk bulat, bentuk gurita/bintang, tidak berpola) atau tidak kompak (bentuk terpecah, berantai, terbelah, bentuk stellar). Kemudian dalam proses perembetan juga bisa dilihat mengalami perembetan konsentris, memanjang atau meloncat. Juga akan ditemukan faktor yang mempengaruhi terbentuknya kota, yaitu faktor bentang alam/geografis, sosial, ekonomi, transportasi dan regulasi. Berdasarkan pengamatan pada peta maka pola struktur jalan terbentuk seperti pada Gambar 12. 

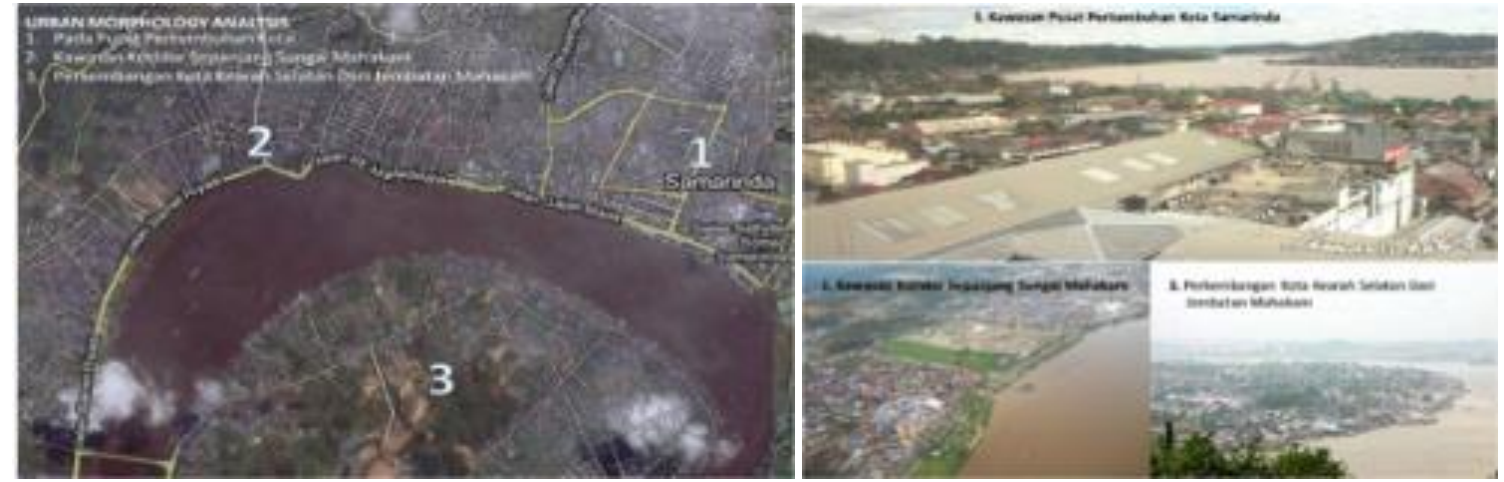

Gambar 11. Peta dan foto kota Samarinda untuk menerapkan analisa urban morfologi, Sumber: Bappeda Kota Samarinda dan google.co.id/maps/kota-samarinda(2012)
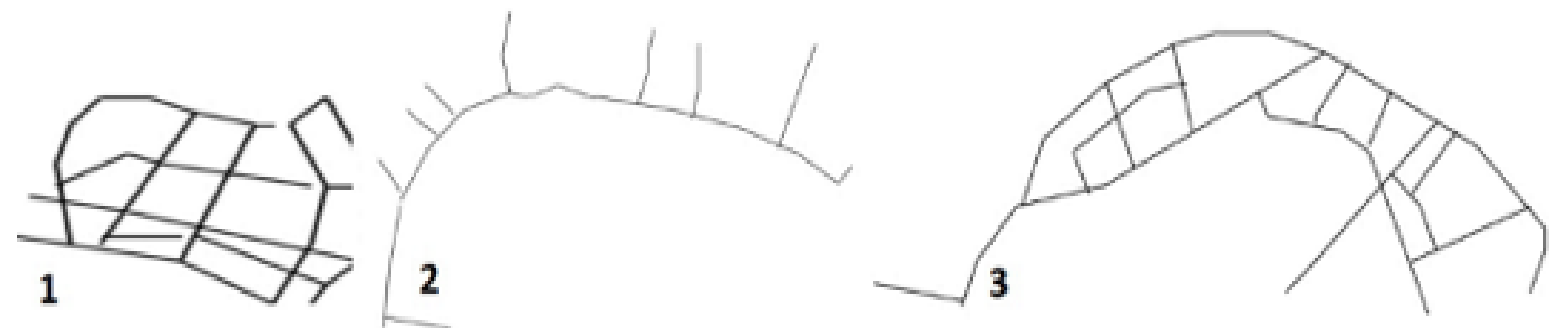

Gambar 12. Pola struktur jalan pada kota lama (1), kawasan koridor sungai Mahakam (2), Samarinda Seberang untuk perkembangan kota ke arah selatan dari jembatan Mahakam (3),

Sumber: plot model jalan pada peta-jalan.com/kota-samarinda-kalimantan-timur/ (2012)
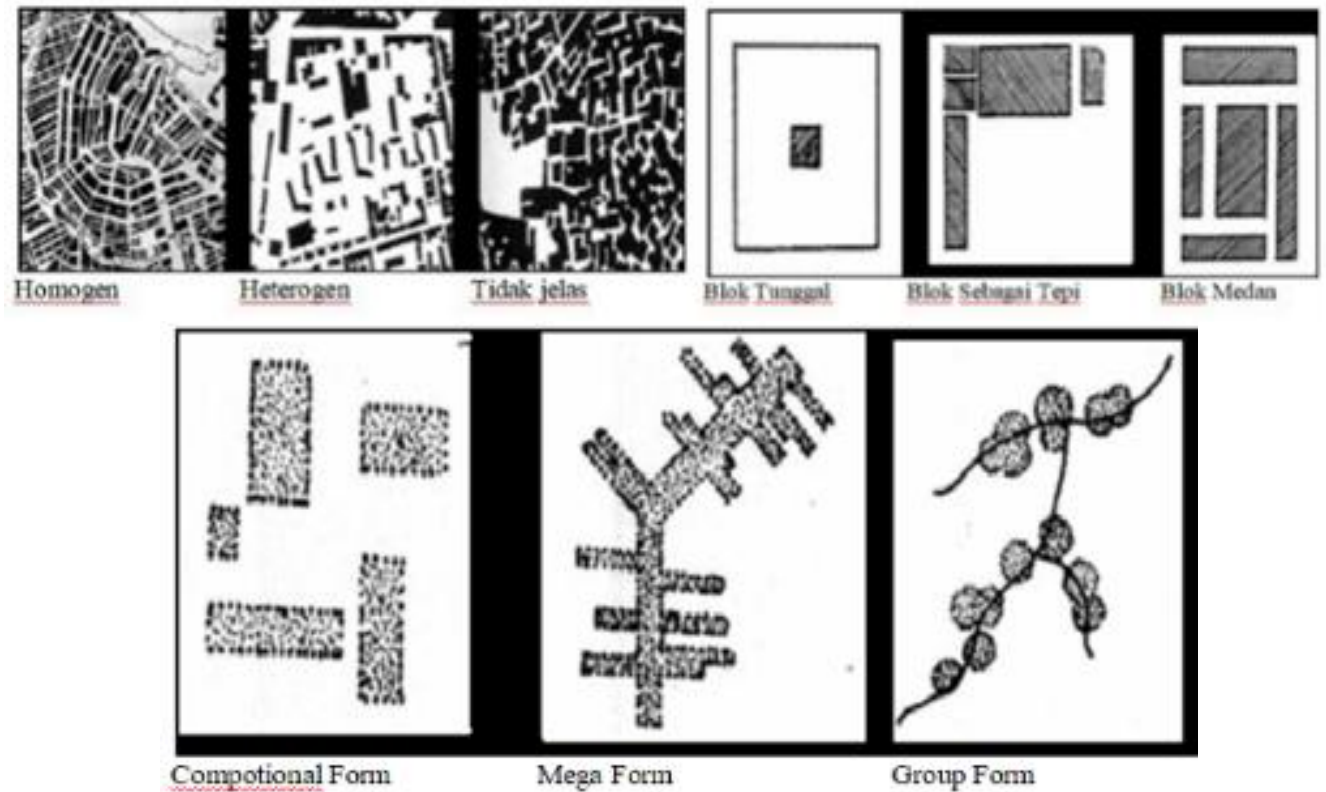

Mega Form

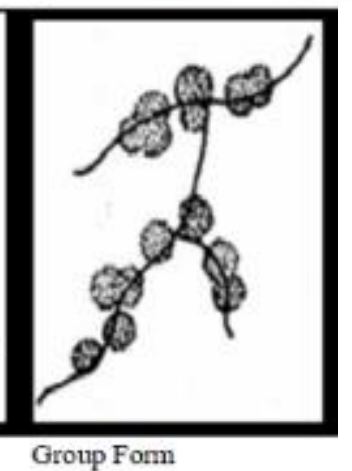

Gambar 13. Contoh bentuk tipo morfologi kota sebagai pembanding dalam menganalisa morfologi kota Samarinda,

Sumber: Markus Zahnd (2006) 
Bila diperbandingkan dengan beberapa pola yang ada pada Markus Zahn (2006) seperti pada Gambar 13, maka dapat dilihat bahwa beberapa pola struktur jalan di kota Samarinda menunjukkan:

- Dari pola massa bangunan dan ruang terbuka terbentuk pola grid.

- Dari tipologi elemen terbentuk sistem terbuka linear.

- Dari tipologi massa bangunan terbentuk blok medan.

- Dari tekstur masa bangunan dan ruang terbuka terbentuk homogen.

- Dari pola struktur ruang kota terbentuk mega form.

\section{KESIMPULAN}

1. Adanya suatu keterbatasan dan kekurangan dalam mendapatkan data eksisting fisik kota sangat mempengaruhi hasil yang didapatkan dari teknik analisa kota yang dipakai dalam studi di kota Samarinda.

2. Pada dasarnya melihat Teknik analisa kota yang dipakai tidak secara murni diterapkan seluruhnya sesuai standar yang ada, tapi mengalami penyesuaian dan modifikasi atau bahkan penggabungan dari satu teknik analisa dengan beberapa teknik analisa yang tercakup dalam Urban Design Tool Kit (Ministry for the Environtment,2006).

3. Dalam penggunannya untuk analisa sebuah kota, maka teknik analisa satu dengan lainnya yang dipakai saling mendukung satu sama lainnya, dalam arti kelemahan salah satu teknik analisa ditutupi dengan kelebihan teknik analisa lainnya, sehingga secara menyatu dapat menyimpulkan suatu karakteristik sebuah kota.

4. Kota Samarinda secara kompleks terbentuk karena dipengaruhi kegiatan transportasi air dan geografi alamnya dengan adanya sungai yang membelah kota yang menjadikan ciri khusus dan ciri khasnya sebagai kota air atau kota sungai. Letak kota lama Samarinda berada pada posisi strategis pada jalur perdagangan dimasa lalu dengan adanya transportasi air yang berkembang dan tumbuh sampai sekarang dengan kebijakan pemerintah setempat diarahkan ke Selatan atau di Samarinda seberang.

5. Dalam melakukan pengembangan ruang kota Samarinda perlu melihat potensi pola struktur ruang kota pada struktur jalan yang terbentuk dari masa dulu sampai sekarang yang memberikan karakeristik tersendiri pada kota. Karakteristik kota Samarinda diantaranya adalah:

a. Massa bangunan dan ruang terbuka membentuk pola grid, terutama yang berada pada koridor sungai Mahakam beserta anak sungainya.

b. Dengan adanya pola grid diatas sangat mempengaruhi tipologi massa bangunan membentuk blok medan dan tekstur massa bangunan beserta ruang terbuka membentuk homogen.

c. Adanya sungai besar yang membelah kota Samarinda memberikan ciri khas tipologi elemen membentuk sistem terbuka linear dan pola struktur ruang kota membentuk mega form. Hal ini terjadi adanya jalan yang menyusuri tepi sungai sampai jauh sekali dan membentuk anak cabang jalan dan memberikan bentukan massa bangunan yang berkelompok.

6. Citra kota Samarinda.

a. Path.

Citra kota dapat ditunjukkan pada jalur jalan yang terdapat pada ruas Jl. Gajah Mada, Jl. R.E. Martadinata dan J1. Selamet Riyadi dengan satu kesatuan ciri khasnya dalam menyelesaikan tekstur jalur pejalan kaki, jalan kendaraan, street furniture dan penataan rthnya.

b. Edge.

Sungai Mahakam sebagai pembatas tepian pada koridor jalan belum diselesaikan secara baik untuk menunjukkan citra kotanya. 
c. Distrik.

Citra kotanya dapat ditunjukkan pada kawasan yang spesifik pada Jl. R.E. Martadinata sebagai kawasan kuliner dan ruko sebagai tempat perdagangan dan jasa. Pada jl. Gajah Mada sebagai kawasan kantor dan dinas pemerintahan dengan adanya kantor perusahaan swasta, BTN, PLN, Kantor Pos, Bank Indonesia, Kantor Gubernur, Korem dan Rumah Jabatan Lamin Etam.

d. Nodes.

Belum ada karakteristik yang menunjukkan citra kota pada pertemuan simpul jalan pada Jl. Slamet Riyadi, Jl. Antasari dan J1. R.E. Martadinata.

e. Landmark.

Areal Islamic Center yang terdapat pada jl. Selamet Riyadi merupakan bentuk landmark yang bisa menunjukkan citra kota. Disamping itu juga terdapat gedung Kantor Gubernur dan Rumah Jabatan Lamin Etam yang bisa menjadi landmark di Jl. Gajah Mada sebagai penanda untuk menunjukkan citra kota.

7. Jati diri kota Samarinda.

Samarinda terdapat sungai Mahakam yang cukup lebar dengan adanya kehidupan ikan pesut. Ikan pesut ini menjadi icon kota Samarinda sebagai jati diri kota. Icon dalam bentuk ikan pesut ini dijadikan penanda dalam bentuk lampu penerangan jalan, patung air mancur dan lampion yang dibangun pada setiap ruas jalan tertentu yang strategis pada tepi sungai Mahakam serta bagian taman lainnya.

8. Identitas kota Samarinda.

Dengan adanya sungai yang cukup lebar terdapat kegiatan transportasi air sebagai identitas kota Samarinda. Hanya sayangnya fasilitas pendukung untuk kegiatan ini belum dilakukan untuk menguatkan identitas kota Samarinda.

9. Image lingkungan.

Secara image lingkungan dalam kalangan masyarakat luar dan masyarakat kota Samarinda, kota ini dikenal dengan sarungnya yang merupakan hasil kerajinan tenun masyarakatnya. Sarung Samarinda menjadi karakteristik khusus sebagai image lingkungan yang diterapkan motifnya pada setiap gerbang masuk ke sekolah negeri dan gapura masuk pada setiap gang atau jalan tertentu pada pelosok kota Samarinda.

10. Makna koridor.

Makna koridor untuk menandai setiap ruas jalan mempunyai fungsi tertentu belum ditunjukkan disini. Koridor yang ada mempunyai fungsi yang sama hanya sebatas sebagai jalur pejalan kaki dan kendaraan motor.

\section{REKOMENDASI}

1. Pada dasarnya dengan dipakainya teknik analisa yang ada akan memberikan kejelasan terhadap keberadaan kota Samarinda untuk kepentingan arahan kebijakan pengembangan kota kearah yang lebih baik dengan memperhatikan hal-hal berikut ini.

a. Tipikal Struktural sebuah Kota yang sudah terbentuk sebaiknya perlu dijaga dan dipertahankan sebagai ciri khas sebuah kota dengan menata bentukan yang berkarakteristik pada elemen pembatas seperti sungai dengan jalan dan areal hijau.

b. Tipologi elemen, masa bangunan, tekstur dan pola ruang kota yang perlu dikembangkan dan ditingkatkan penataannya agar bisa memberikan nilai lebih terhadap citra kota dan identitas kota.

c. Arah pertumbuhan kota yang bermula dari asal usul letak kota lama yang pertama kali terbentuk dan berkembang seperti sekarang ini. Hal ini perlu dijaga pola ruangnya dan dikembangkan potensi yang punya ciri khas agar membentuk jati diri, image lingkungan dan makna koridor. 
2. Jalan pada koridor sungai tidak semuanya menyusuri tepi sungai. Sebaiknya bila dimungkinkan bisa disatukan jalur jalan yang mendekati tepi sungai untuk menyatukan koridornya untuk jalan dan mengembangkan struktur jalannya sebagai kota sungai. Terkecuali disini yang tidak bisa dirubah adalah dikarenakan faktor geografi yaitu adanya lahan kontur yang berbukit. Dengan demikian jalan yang menyusuri sungai ini menjadi ciri khas kota sungai.

3. Karakteristik bangunan yang terbentuk pada koridor sungai menunjukkan adanya perpaduan antara lain adalah:

a. Perpaduan antara daerah perkantoran provinsi yang akan berkembang disini yang berada pada areal perumahan tertata dan permukiman alami yang sebagian besar berada diatas sungai.

b. Perpaduan perkantoran pemerintah, perkantoran swasta dan usaha jasa dan perdagangan dengan adanya ruko-ruko yang mengalami perkembangan fisik yang tidak teratur tata ruang kotanya.

c. Perpaduan perkantoran swasta, pendidikan, usaha dan jasa perdagangan.

d. Perpaduan usaha, jasa perdagangan dan kegiatan industri yang mendominasi areal koridor jalan.

Beberapa hal diatas sangat mendasar untuk segera dilakukan penataan dan penertiban bahu jalan agar bisa memperbaiki bentuk morfologi maupun tata ruangnya agar teratur, terintegrasi dan terakses sirkulasi jalannya dengan baik.

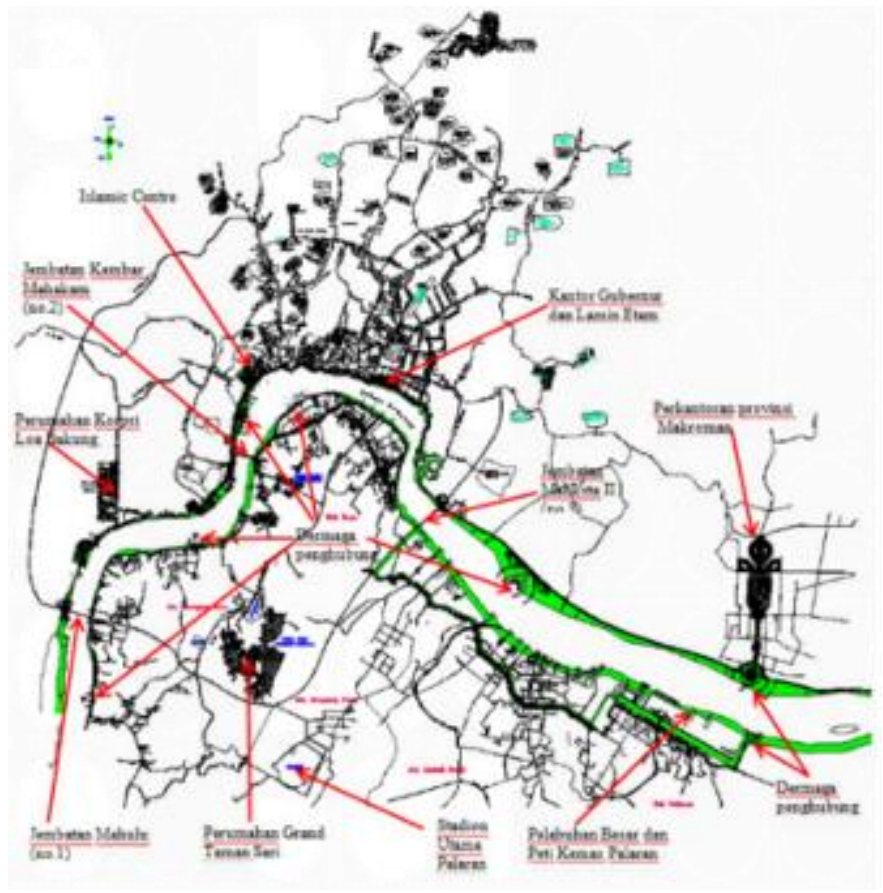

Gambar 14. Alternatif rancangan fisik koridor sungai Mahakam di Samarinda, Sumber: Gagasan ide pribadi (2015)

4. Potensi elemen kota perlu diperhatikan dalam pengembangan penataan ruang kotanya yaitu pada:

a. Potensi elemen fisik pathways, nodes yang perlu dikembangkan penataannya secara optimal dan menyeluruh. Terutama pada pertemuan Jl. Selamet Riyadi, Jl. Antasari dan Jl. R.E. Martadinata agar bisa membentuk citra kota.

b. Selain Islamic Centre dan bangunan kantor pemerintahan pada koridor sungai maka ada beberapa lokasi yang punya potensi menjadi landmark. Potensi tersebut ada pada 
lahan-lahan tidur dan lahan-lahan yang cenderung akan menjadi lahan tidur akibat tidak adanya kegiatan operasional kedepannya nanti yang mempunyai letak strategis pada koridor sungai Mahakam (Rochdi, 2018)

5. Perlunya alternatif rancangan fisik koridor sungai dalam penataan ruang kotanya yang memperlihatkan karakter kota sungai dengan cara membentuk fisik tepi sungai berupa:

a. Taman dan penghijauan mengikuti bentuk tepi alur sungai.

b. Bentukan fisik fasilitas tepi sungai seperti dermaga sebagai penunjang transportasi air dan lansekap taman pada ruang terbuka. Fasilitas ini perlu dekat dengan prasarana umum maupun pemerintah yang bersifat rekreatif dan mendukung wisata air mengikuti bentuk bias/riak air yang cenderung melingkar atau berbentuk lingkaran.

\section{UCAPAN TERIMAKASIH}

Diucapkan terima kasih untuk Dewan Redaksi yang memberikan kesempatan untuk dapat dimuat dalam Jurnal Riset Kaltim ini, segenap civitas akademika UNU Kaltim, dan ibu Prof. Ir. Endang Titi Sunarti BD. M.Arch., Phd selaku dosen pengampu mata kuliah Morfologi Ruang Kota-S2 Arsitektur ITS Bidang Keahlian Perancangan Kota.

\section{DAFTAR PUSTAKA}

Cullen, Gordon. (1961). Townscape. London: The Architectural Press.

Darjosanjoto, Endang TS, (2006), Penelitian Arsitektur Di Bidang Perumahan Dan Permukiman, cetakan pertama, ITS press, Surabaya.

Faqih, Muhammad dan BD, Endang Titi Sunarti dan Rochdi, Edith Abram. (2016). Penataan Distrik Berkarakter Kota Sungai di Makroman Samarinda. Jurnal Berkala Ilmu EkonomiNeo Bis, 10(1), 91-104.

Kostof, Spiro. (1991). The City Shaped Urban Pattern and Meanings Through History. London: Thames and Hudson Ltd. London.

Krier, Rob. (1979). Urban Space. London: Academy edition.

Lynch, Kevin. (1960). The Image of The City. Cambridge: MIT Press.

Lynch, Kevin. (1976). Managing The Sense Of The City, Cambridge: MIT Press.

Ministry for the Environment. (2006). Urban Design Toolkit Third Edition. New Zealand: Ministry for The Environment.

Moudon, Anne V. (1997). Urban Morphology as an Emerging. Interdisciplinary Field. Urban Morphology. Vol. 1, 3-10.

Parsons, Adam. (2010). Site: Serial adamparsonsdesignthesis.blogspot.com/2010/12/site-serial-views.html, diakses pada tanggal 24 Februari 2015.

Republik Indonesia. (1997). Peraturan Pemerintah No. 47/PP/1997 mengenai Rencana Tata Ruang Wilayah Nasional. Jakarta.

Rochdi, Edith Abram Rochdi. (2018). Pemanfaatan Lahan Tidur Untuk Landmark di koridor sungai Mahakam. Buku: Antalogi Kota Indonesia. Warmadewa Research Centre. Bali. Indonesia. 
Pengembangan Ruang Kota Samarinda Dengan Menerapkan Metode Teknik Analisa Urban

Edith Abram Rochdi

Rochdi, Edith Abram. (2015). Penataan Koridor Sungai Mahakam di Kota Samarinda, Kalimantan Timur. Tesis Program Pascasarjana Bidang Keahlian Perancangan Kota Jurusan Arsitektur FTSP ITS Surabaya.

Rochdi, Edith Abram. (2017). Penataan Ruang Terbuka Bigmall Samarinda Agar Berkarakter Kota Sungai. Jurnal Riset Kaltim, 5(2), 155-168.

Yunus, Sabari Hadi. (2002). Struktur Tata Ruang Kota. Cetakan ke 3. Yogyakarta: Pustaka Belajar.

Zahnd, Markus. (2006). Perancangan Kota Secara Terpadu. Teori perancangan kota dan penerapannya. Cetakan ke 2. Yogyakarta: Kanisius. 